\title{
Adult and juvenile dermatomyositis: are the distinct clinical features explained by our current understanding of serological subgroups and pathogenic mechanisms?
}

\author{
Sarah L Tansley', Neil J McHugh' and Lucy R Wedderburn*
}

\begin{abstract}
Adult and juvenile dermatomyositis share the hallmark features of pathognomic skin rash and muscle inflammation, but are heterogeneous disorders with a range of additional disease features and complications. The frequency of important clinical features such as calcinosis, interstitial lung disease and malignancy varies markedly between adult and juvenile disease. These differences may reflect different disease triggers between children and adults, but whilst various viral and other environmental triggers have been implicated, results are so far conflicting. Myositis-specific autoantibodies can be detected in both adults and children with idiopathic inflammatory myopathies. They are associated with specific disease phenotypes and complications, and divide patients into clinically homogenous subgroups. Interestingly, whilst the same autoantibodies are found in both adults and children, the disease features remain different within autoantibody subgroups, particularly with regard to life-threatening disease associations, such as malignancy and rapidly progressive interstitial lung disease. Our understanding of the mechanisms that underlie these differences is limited by a lack of studies directly comparing adults and children. Dermatomyositis is an autoimmune disease, which is believed to develop as a result of an environmental trigger in a genetically predisposed individual. Age-specific host immune responses and muscle physiology may be additional complicating factors that have significant impact on disease presentation. Further study into this area may produce new insights into disease pathogenesis.
\end{abstract}

\section{Introduction}

Dermatomyositis (DM) is an idiopathic inflammatory myopathy, characteristic features of which are inflammation of skeletal muscle causing weakness, and pathognomic skin rashes, including periorbital heliotrope discoloration and Gottron's papules. It is a heterogeneous disease and clinical manifestations range from a relatively mild disease responsive to immunosuppressive treatment, to that causing significant morbidity and mortality. Whilst both adult DM and juvenile DM (JDM) share the pathognomic hallmarks of this disease, the frequency of complications and associated features varies considerably between the two groups. For example, leading causes of mortality in adults with DM are associated malignancy

*Correspondence: I.wedderburn@ucl.ac.uk

${ }^{2}$ Rheumatology Unit, UCL Institute of Child Health, 30 Guilford Street,

London WC1N 1EH, UK

Full list of author information is available at the end of the article and interstitial lung disease (ILD). These are, however, both rare in children. Here we will discuss the important clinical differences between adult and juvenile disease, then consider serological and genetic differences that may provide insights into the pathogenic mechanisms that could underlie these differences.

\section{Clinical features}

$\mathrm{DM}$ is a rare disease. The incidence varies depending on the population and ethnicity studied and is approximately 9.63 per million adults [1] and 1.9 to 4.1 per million children [2,3]. JDM is the most common of the childhood idiopathic inflammatory myopathies, whereas in adults polymyositis is more common than DM in Caucasian populations. Although proximal muscle weakness and rash are characteristic of both age groups, differences also exist between these cardinal features in the disease groups. Thus, the rash of JDM can be atypical, occurring anywhere in the body, and is more frequently associated with ulcerative change than in adults [4]. 
Both JDM and adult DM are heterogeneous disorders, and clinical outcome is highly variable. In children early studies described three groups: those with monocyclic (permanent remission within 2 years), polycyclic (periods of remission followed by relapse) and chronic continuous disease. Although modern treatment has improved outcomes, recent long-term outcome studies still show significant numbers of patients with ongoing disease or damage [5,6]. Inadequate or delayed treatment has been shown to be an important factor in predicting a chronic course and poor outcome, while several studies suggest that aggressive early treatment results in lower morbidity and improved outcome [7-9].

Laboratory tests such as creatinine kinase are less likely to be elevated in JDM than adult DM and therefore other myositis-associated enzyme levels (such as aldolase, lactate dehydrogenase and transaminases) are also tested [10]. Amyopathic myositis is rare in children; more often patients have mild muscle disease or progressive muscle disease that was not detected on earlier assessment $[1,11,12]$. Studies of disease outcome in juvenile and adult myositis are difficult to compare due to the lack of standardised outcomes. Overall, however, whilst JDM may have a rapid onset and is associated with considerable morbidity, and even mortality, it appears to have a better prognosis than adult disease if treated appropriately in terms of recovery of both muscle power and function.

\section{Malignancy}

In adults there is a clearly established association between DM and the development of malignancy. In all patients with idiopathic inflammatory myopathy the incidence of cancer is 7 to $30 \%[2,13,14]$. The increased risk is higher in patients with DM than polymyositis, and overall there is a threefold increase in risk of malignant disease for all cancer types after diagnosis of DM [4,15].

Whilst no specific cancer subtype is associated with DM, and an increased risk of all cancer histological subtypes is seen, approximately $80 \%$ of associated malignancies are adenocarcinomas $[5,6,15]$. The risk of malignancy is highest in the first year after diagnosis and reduces thereafter [7-9,15]. Malignancy can also predate the diagnosis of myositis, and the clustering of cancer cases before diagnosis of myositis suggests that the association is not merely the result of increased cancer surveillance in patients with known myositis $[10,14,15]$. Two studies showed that the risk of cancer remained increased up to 5 years after the diagnosis of myositis $[15,16]$.

It has been suggested that DM in adults should be considered a paraneoplastic syndrome. Certainly DM has been noted to improve with treatment of an associated cancer, and muscle weakness to recur at relapse of malignant disease, further suggesting a paraneoplastic origin [15]. This appears to apply to a subgroup of patients, however, and given that the average age of onset in adults is 50 to 60 years, the longer patients survive the more likely they are to develop non-myositis-associated cancers.

In contrast, to date, JDM has not been clearly associated with malignancy and cases of malignancy in children with JDM are limited to case reports [17]. Routine malignancy screening is not therefore generally performed in children unless unusual features are present, for example, splenomegaly. Interestingly, amongst adult DM patients, younger patients have a lower risk of associated malignant disease than those aged over 45 years [15]. This may reflect the general increased risk of malignant disease with increasing age, and different triggers for myositis according to age. In the UK JDM Cohort Study, now comprising >390 children, the majority with JDM, there have been no reported malignancies (LW, unpublished observations). However, longterm follow-up is needed to ascertain the malignancy risk of these individuals in adult life.

\section{Lung disease}

Lung disease in myositis includes aspiration pneumonia, respiratory muscle weakness and ILD. ILD is a significant cause of mortality in adults with DM and is associated with a poorer prognosis $[18,19]$. ILD affects 20 to $65 \%$ of adults with idiopathic inflammatory myopathy [20]. However, prevalence varies with the means of detection and the wide range of reported prevalence is likely to reflect the lack of a standard screening approach in newly diagnosed patients. Increased awareness of ILD as a presenting symptom, and improved diagnostic techniques have led to increasing rates of ILD in myositis patient cohorts; $19 \%$ of idiopathic inflammatory myositis patients present with ILD prior to muscle weakness [21]. ILD in adult myositis can run a rapidly progressive course or a chronic course. In a study of 36 adult patients with ILD, $58 \%$ had a chronic course, $25 \%$ were asymptomatic and $17 \%$ presented with acute respiratory failure [21]. In a retrospective study of Korean myositis patients, ILD was observed in $40.3 \%$, and was associated with reduced survival. Poor prognostic markers were a Hamman-Richlike (acute interstitial pneumonitis) presentation, amyopathic dermatomyositis and an initial forced vital capacity $<60 \%$ [19]. Prospective studies suggest a $40 \%$ increase in mortality associated with ILD in adult patients with idiopathic inflammatory myositis [22].

Rapidly progressive ILD is frequently associated with amyopathic DM (patients with the characteristic skin rashes but without muscle weakness or raised muscle enzymes). This phenotype is more commonly seen in Eastern Asia [23]. These patients are often resistant to 
intensive therapy with high dose corticosteroids and immunosuppressive treatments, leading to respiratory failure and death. Associated mortality is high.

Several pathologic patterns of ILD are found in myositis, and as with other causes of ILD, the pathologic appearance impacts on prognosis regardless of the underlying aetiology: non-specific interstitial pneumonia (NSIP) is associated with a better prognosis than other subtypes. Connective tissue disease-associated ILD, including histopathologic subtypes, has been recently reviewed [24]. Diagnosis on CT chest patterns in patients with anti-Jo1 antibodies and anti-synthetase syndrome showed a preponderance of NSIP affecting $50 \%$ and usual interstitial pneumonia (UIP) affecting 30\%. Surgical biopsy patterns were different, however, with diffuse alveolar damage in $55 \%$ and UIP in $45 \%$ and NSIP in $15 \%$ [25]. This may reflect a selection bias for performing biopsies in patients presenting with acute interstitial pneumonia or those who are not responding well to treatment. Another study looking at similar patients with anti-PL12 antibodies showed a similar incidence on biopsy or CT consistent with UIP in $45 \%$ of patients, $16 \%$ NSIP and 16\% cryptogenic organising pneumonia [26]. This is in contrast to an earlier study of 17 adult idiopathic inflammatory myositis patients all of whom underwent biopsy. NSIP was seen in 11 cases $(65 \%)$ and UIP in 4 cases [22].

Although data on pulmonary involvement in JDM are limited, reported rates of lung disease in JDM are far less common than in adult DM [27]. Asymptomatic impairment in pulmonary function has been reported to be common, with $40 \%$ of affected children having abnormal pulmonary function tests [28]. Radiographically proven ILD is rare, however. Kobayashi [29] reported five cases of JDM-associated ILD: lung disease progressed despite treatment and was refractory to methylprednisolone in all cases. One patient died of respiratory failure. No patient underwent lung biopsy but radiological diagnoses were interstitial pneumonia in three cases and bronchiolitis obliterans organising pneumonia in two cases. The apparent incidence of JDM-associated ILD in this study was $50 \%$, much higher than reported elsewhere, which may reflect referral bias to a specialist hospital [29]. Genetic and environmental factors may also have a role to play. It has been speculated that abnormal pulmonary function tests and asymptomatic high-resolution computed tomography (HRCT) abnormalities seen in JDM may represent a background of subclinical ILD that responds well to conventional immunosuppressive treatment, and therefore needs no further action [29]. A small study looking at the pulmonary outcome in JDM found that, on follow-up, JDM patients had smaller lung volumes than controls, and that $75 \%$ had impaired diffusion, restriction or an HRCT abnormality [30].
Given that HRCT abnormalities correlated with cumulative organ damage and poorer patient-reported health status, the authors speculated that lung symptoms may have been masked by damage to different organ systems, which in turn limit exercise capacity. Thus, some degree of pulmonary involvement in JDM may be higher than previously recognised. However, a recent outcome study comparing adults with children found only $3.5 \%$ of children with JDM, compared to $49 \%$ of adults with DM $(P<0.001)$, to have pulmonary damage at long-term follow-up [6].

\section{Calcinosis}

Calcinosis is a relatively common disease manifestation in JDM and occurs in up to $30 \%$ of cases; it is a cause of considerable morbidity, and can lead to skin ulceration, pain from nerve entrapment and joint contractures [4,6,31]. It typically occurs 1 to 3 years after JDM diagnosis, but may develop at the onset of illness or up to 20 years later [32]. Calcinosis most frequently affects pressure areas such as the elbows, knees, buttocks and digits. It is associated with delayed diagnosis, a chronic disease course and inadequately treated disease $[7,10]$. Increased local production of the proinflammatory cytokine TNF $\alpha$ has been associated with the development of calcinosis and therefore the intensity of inflammation may contribute [33]. The UK JDRG cohort study found the frequency of calcinosis to be $12 \%$ of children [4]. The lower frequency than in other studies may reflect earlier diagnosis and more aggressive treatment in the UK JDRG cohort, or relatively short follow-up in some patients at the time of analysis. Calcinosis is less common in adult patients and when present appears to occur later in the disease course [34].

Whilst the associated clinical features of ILD, malignancy and calcinosis contribute to the morbidity and mortality observed in DM, the differences between adult and childhood disease extend beyond these key well studied complications. Other important disease associations include skin ulceration, and major organ vasculopathy (in particular gut, cardiac, and central nervous system), which are known to be much more common in JDM than in adult disease [35].

\section{Pathogenesis}

Comparisons of the pathogenesis of adult DM and JDM are hampered by the fact that few studies have directly compared the two groups. Studies in this area tend to be limited to modelling adult or juvenile disease, or because of the rarity of the conditions, have included both adults and children and combined the results. The pathological findings in muscle in adult and juvenile myositis have recently been comprehensively reviewed [27]. 


\section{Age of onset}

Not only are there differences in the clinical phenotype of adult DM and JDM, but also within each subgroup age of onset appears to influence disease features and outcome. A recent study comparing children whose JDM starts before the fifth birthday with those who have onset after 5 years, suggests that young age of onset is associated with more ulceration and generalised oedema, both considered to be poor prognostic features [36]. Interestingly, adapting a major histocompatibility complex (MHC) class I heavy chain overexpressioninduced mouse model of DM, so that MHC class I protein was expressed from a younger age, resulted in a more severe disease phenotype with rapid onset of weakness and even early death [37]. Histological analysis did not suggest a different inflammatory process but rather more rapid kinetics. Younger more rapidly growing muscle tissue may be more sensitive to disturbances in the balance of myoblasts to myofibres, and changes in these pathways could induce more rapid overall muscle damage [37]. These studies suggest that differences in physiology at varying ages impact on the pathophysiology of myositis disease, with young muscle perhaps being more sensitive to stressful stimuli. However, considerable data also suggest that, in model systems, young muscle is more able to recover from injury than old muscle, perhaps due to a difference in satellite cell activity [38].

\section{Myositis-specific autoantibodies}

Myositis-specific autoantibodies (MSAs) can now be identified in $80 \%$ of adults [39] and $>60 \%$ of children with myositis (NM and ST, personal data). These serological markers help define distinct clinical subsets and can predict the likelihood of developing complications $[39,40]$ (Table 1$)$. In DM the same autoantibodies are seen in both adult and juvenile forms, and specific associations between HLA risk alleles and serology are common across the age range, suggesting similarities in the underlying pathogenesis. The frequency of MSA subgroups varies between adult and juvenile disease and the population studied. The specific disease phenotype for autoantibody subgroups also varies depending on the population studied and between adults, children and even young adults. It remains unclear whether these autoantibodies themselves contribute to pathology and, if so, how age and ethnic background/environmental effects are mediated.

Anti-Jo1 and other anti-synthetase autoantibodies, including anti-PL-7, PL12, EJ, OJ, KS, Ha and Zo, are the most common and well described MSAs found in adult myositis Caucasian populations, and can be identified in approximately $40 \%$ of those with idiopathic inflammatory myopathies. tRNA-synthetases are cytoplasmic enzymes that catalyse the binding of amino acids to their cognate
tRNAs. Autoantibodies are found in patients with a distinct clinical phenotype known as the anti-synthetase syndrome, comprising myositis, ILD, arthritis, fever, Raynaud's phenomenon and mechanic's hands. Patients can also have DM skin lesions, including Gottron's papules [41]. The risk of ILD is significantly higher in this patient subgroup. The prevalence of ILD in anti-Jo1positive patient cohorts has been found to be $86 \%$ [25] and 90 to $100 \%$ in patients with anti-PL12 [26,42]. ILD is a major cause of morbidity and mortality in the antisynthetase syndrome [22]. Although this group of autoantibodies is common in adult myositis, it is rare in JDM. Where anti-Jo1 autoantibodies have been identified in JDM, however, affected children may have clinical features similar to anti-synthetase syndrome in adults $[43,44]$.

Anti-Mi2 is the 'classic' DM autoantibody discovered in $20 \%$ of adult patients and 4 to $10 \%$ of those with JDM. It is associated with hallmark cutaneous features and milder muscle disease. It carries a good prognosis in adults and children [43-46]. Anti-p155 (anti-TIF1 $\gamma$ ) is found in 13 to $21 \%$ of adults with DM, usually in association with anti-TIF1 $\alpha$ (anti-p155/140) and occasionally anti-TIF1 $\beta$ [47]. It is strongly associated with the development of malignancy, and more so when found in combination with anti-TIF1 $\alpha$ [47-49].

More than $50 \%$ of adults with this autoantibody will develop an associated malignancy within 3 years of diagnosis. Anti-p155/140 is also the most common autoantibody found in JDM (23\%) where no associated malignancy is seen [50]. Interestingly, like children, young adults with anti-p155 do not appear predisposed to malignancy [47]. Both adults and children with this MSA have worse cutaneous involvement, and in children there is also a trend towards worse muscle weakness $[48,50]$. An association between anti-p155 and generalised lipodystrophy has also been reported in JDM [51].

Anti-NXP2 (also known as p140 or MJ) is another common JDM MSA, found in 11 to $23 \%$ of affected children [52,53]. In JDM, anti-NXP2 antibody is associated with a more severe disease course, with worse functional status and more persistent disease activity [52], and positivity for this autoantibody is strongly associated with the development of calcinosis [53]. AntiNXP-2 autoantibody is uncommon in adults $(1.6 \%$ of patients) [54]. Disease associations in adults have yet to be firmly established but a small study has recently demonstrated a possible association with malignancy, with three of the eight anti-NXP2 antibody-positive study patients developing malignancy within 3 years of presentation, and a fourth patient 42 months prior to DM presentation [54]. This finding was not replicated in a recent study of adult myositis Italian patients where, surprisingly, anti-NXP2 was the most common 
Table 1. Environmental and clinical associations of autoantibody subgroups

\begin{tabular}{|c|c|c|c|c|c|c|}
\hline $\begin{array}{l}\text { Myositis-specific } \\
\text { autoantibody }^{\text {a }}\end{array}$ & $\begin{array}{l}\text { Antibody } \\
\text { target }\end{array}$ & $\begin{array}{l}\text { Environmental/ } \\
\text { genetic } \\
\text { associations }\end{array}$ & $\begin{array}{l}\text { Frequency } \\
\text { in juvenile } \\
\text { IIM (\%) }\end{array}$ & $\begin{array}{l}\text { Juvenile } \\
\text { disease } \\
\text { features }\end{array}$ & $\begin{array}{l}\text { Frequency } \\
\text { in adult } \\
\text { IIM (\%) }\end{array}$ & $\begin{array}{l}\text { Adult } \\
\text { disease } \\
\text { features }\end{array}$ \\
\hline $\begin{array}{l}\text { Jo1, PL-7, PL-12, EJ, } \\
\text { OJ, KS, Ha, Zo [39] }\end{array}$ & $\begin{array}{l}\text { tRNA synthetases: catalyse } \\
\text { amino acid binding to their } \\
\text { cognate RNAs [39] }\end{array}$ & $\begin{array}{l}\text { Onset in spring } \\
{[74,75]}\end{array}$ & $1-5[43,44]$ & Rare $[40,41]$ & 40 [39] & $\begin{array}{l}\text { Anti-synthetase } \\
\text { syndrome }[39,41]\end{array}$ \\
\hline $\mathrm{Mi2}$ & $\begin{array}{l}\text { Nucleosome remodelling } \\
\text { deacetylase complex } \\
\text { (NuRD) [39] }\end{array}$ & $\begin{array}{l}\text { UV light exposure } \\
{[76]}\end{array}$ & $4-10[39,43,46]$ & $\begin{array}{l}\text { Classic DM, mild } \\
\text { disease }[43,46]\end{array}$ & $20[39,45]$ & $\begin{array}{l}\text { Classic DM, mild } \\
\text { disease [39] }\end{array}$ \\
\hline $\begin{array}{l}\text { P155-TIF1Y/ } \\
\text { TRIMM33 } \\
\text { (transcriptional } \\
\text { intermediary } \\
\text { factor 1) }\end{array}$ & $\begin{array}{l}\text { Nuclear factor: acts as } \\
\text { ubiquitin ligase for SMAD4. } \\
\text { SMAD4 contributes to TGF } \beta \\
\text { signalling, suppressing cell } \\
\text { growth [68] }\end{array}$ & $\begin{array}{l}\text { Juvenile disease } \\
\text { trend towards late } \\
\text { winter birth [77] }\end{array}$ & $23[50]$ & $\begin{array}{l}\text { Severe cutaneous } \\
\text { disease [50] }\end{array}$ & $13-21[47]$ & $\begin{array}{l}\text { Severe cutaneous } \\
\text { disease. } \\
\text { Malignancy in } 50 \% \\
{[48,49]}\end{array}$ \\
\hline $\begin{array}{l}\text { P140 - MDA5 } \\
\text { (melanoma } \\
\text { differentiation } \\
\text { associated gene 5) }\end{array}$ & $\begin{array}{l}\text { Cyoplasmic RNA helicase } \\
\text { involved in inate immunity } \\
\text { viral infection response [56] }\end{array}$ & $\begin{array}{l}\text { Increased } \\
\text { prevalence in } \\
\text { Eastern Asia. Rising } \\
\text { frequency in central } \\
\text { Japan }[56-58,78]\end{array}$ & $\begin{array}{l}7 \\
\text { (personal data) }\end{array}$ & $\begin{array}{l}\text { RP-ILD - in Japanese } \\
\text { cohort } \\
\text { Ulceration [62] }\end{array}$ & $13-35[56,58]$ & $\begin{array}{l}\text { Amyopathic DM } \\
\text { Characteristic } \\
\text { cutaneous findings, } \\
\text { ulceration } \\
\text { RP-ILD }[56,58]\end{array}$ \\
\hline $\begin{array}{l}\text { SAE (sumo- } \\
\text { activating enzyme) }\end{array}$ & $\begin{array}{l}\text { Involved in post- } \\
\text { transcriptional modification } \\
{[39,63]}\end{array}$ & & $\begin{array}{l}<1 \% \\
\text { (personal data) }\end{array}$ & Very rare & $8.4[63]$ & $\begin{array}{l}\text { Initially amyopathic } \\
\text { disease } \\
\text { Dysphagia [63] }\end{array}$ \\
\hline $\begin{array}{l}\text { SRP (signal } \\
\text { recognition } \\
\text { peptide) }\end{array}$ & $\begin{array}{l}\text { Cytoplasmic protein } \\
\text { involved protein recognition } \\
\text { and translocation [39] }\end{array}$ & $\begin{array}{l}\text { Onset in autumn } \\
{[74,75]}\end{array}$ & & Rare $[43,44,66]$ & $5[39]$ & $\begin{array}{l}\text { Necrotising myopathy } \\
{[64,65]}\end{array}$ \\
\hline
\end{tabular}

a 1 1, histydly tRNA synthetase; PL-7, threonyl tRNA synthetase; PI-12, alanyl tRNA synthetase; EJ, glycl tRNA synthetase; OJ, isoleucyl tRNA synthetase; KS, asparaginyl tRNA synthetase; Ha, tyrosyl tRNA synthetase; Zo, phenylalanyl tRNA synthetase. DM, dermatomyositis; IIM, idiopathic inflammatory myopathy; RP-ILD, rapidly progressive interstitial lung disease; TGF, transforming growth factor.

autoantibody identified, and was present in $30 \%$ of DM patients [55]. This study found no association with malignancy but a trend towards increased calcinosis. The discrepancy between this study and those previously published may reflect the younger age of this cohort; only two out of ten anti-NXP2-positive patients were over the age of 50 years.

Anti-MDA5 was initially identified in Japanese DM patients with clinically amyopathic myositis and ILD; a phenotype more commonly seen in Eastern Asia [56]. Studies based in Japan have identified anti-MDA5 in 19 to $35 \%$ of DM patients [56,57]. This MSA has since been identified in Caucasian cohorts but at a lower frequency [58]. In adults it is associated with clinically amyopathic myositis (81\%) and rapidly progressive ILD (74\%) [59]. These patients also typically have characteristic patterns of skin ulceration and painful palmar papules [58]. Because of the association with rapidly progressive ILD, which often responds poorly to immunosuppressive treatment, mortality is high (33\%) and often occurs within 6 months of diagnosis [59,60]. Anti-MDA5 has been shown to be a poor prognostic marker associated with significantly higher mortality at 6 months and 5 years [60].

Of interest, a recent study of 25 newly diagnosed patients with DM-ILD showed significantly different HRCT patterns between anti-MDA5-positive and antiMDA5-negative groups [61]. Whilst $69.2 \%$ of antiMDA5-negative patients had a HRCT pattern suggestive of NSIP, findings in the anti-MDA5-positive group were distinct and more suggestive of organising pneumonia or diffuse alveolar damage. The mortality in the patients with this pattern was high (50\%), suggesting a high prevalence of diffuse alveolar damage. No patients underwent comparative biopsy.

Anti-MDA5 has also been identified in Japanese children with JDM and rapidly progressive lung disease and was associated with a poor response to treatment and increased mortality [62]. The background incidence of JDM-associated ILD in the 13 children included in this study was very high and approached $50 \%$. The reason for this is not clear and the true incidence of ILD and rapidly 
progressive ILD in JDM patients with anti-MDA5 is therefore not completely apparent. It is likely to be significantly less than in adults with the same autoantibody, and within the adult DM population rapidly progressive ILD is more commonly seen in older adults [59].

Anti-SAE autoantibodies have been identified in 8.4\% of adult DM patients [63]. Patients typically present with amyopathic myositis but go on to develop muscle involvement with an increased frequency of dysphagia and reduced risk of ILD. This autoantibody has not been identified in JDM cohorts to date [63]. Anti-SRP autoantibodies are an uncommon but important finding in adult myositis, where they are associated with a necrotising myopathy and profound muscle weakness $[64,65]$. These antibodies have rarely been identified in juvenile cohorts $[43,44,66]$.

\section{Autoimmunity}

The presence of MSAs provides strong evidence for the importance of autoimmune mechanisms in DM. MSAs frequently target nuclear or cytoplasmic cellular components that are involved in gene transcription, protein translocation and antiviral responses. Whilst autoantigens with comparable cellular functions are associated with similar disease phenotypes, there are important differences in clinical features depending on whether these autoantibodies are found in children or adults. It is not yet clear whether these clinical differences relate to differences in the underlying disease trigger and pathogenesis, or are a reflection of differences in cellular processes and immune function in different age groups.

As discussed above, MSA may play a role in the pathogenesis of myositis. An important study by Cascioloa-Rosen [67] looked at myositis-specific autoantigen Mi2 expression in muscle cells. Enhanced autoantigen expression was seen in regenerating muscle cells in DM, with very low levels of expression in control muscle. The authors hypothesised that regenerating muscle may be the ongoing source of antigen supply in myositis, leading to a forward feed-back system and selfsustaining autoimmune response [67]. MSA expression is increased in several cancer cells, but not their associated normal tissues and in cases associated with malignancy, this may provide the initial immune stimulus for autoantibody generation [67]. Interestingly, the antigenic targets of MSAs that have been linked to the development of malignancy both have important roles to play in cell growth and DNA repair: TIF1Y is a nuclear factor that, via SMAD4, plays an important role in transforming growth factor- $\beta$ signalling and suppression of cell growth [68]. NXP2 is essential for regulating the activation and subcellular localisation of tumour suppressor gene p53 [69]. TIF1 and NXP2 proteins have a significant role in oncogenesis and autoantibodies may be produced during misdirected anti-tumour immunity. MSAs have not been identified in patients with malignancy but without DM, thereby implying that the generation of MSAs is crucially linked to the development of DM. Further work is needed to examine the subcellular localisation of more recently identified MSAs in both control and disease muscle, and evaluate any differences between JDM and adult DM muscle.

\section{Environmental factors}

DM is believed to be the result of an autoimmune process that develops in a genetically susceptible individual in response to an environmental trigger. Whilst one such trigger may be malignancy this is not present in all cases and is exceptionally rare in JDM. Similarly, common triggers may exist for malignancy and DM amyopathic myositis in adults, which are not pertinent in childhood.

Several reports have found seasonal associations and spatial clustering in the onset of inflammatory myopathies, and various infectious triggers have therefore been postulated [70-75]. Elevated titers of antibodies to certain viruses in some juvenile and adult patients with myositis, as well as the presence of viral RNA in muscle biopsy specimens, have been reported, but not all studies support these findings [72]. The trigger may vary with the MSAs generated as differences in seasonal onset have been found between autoantibody subgroups with a clustering of myositis associated with anti-Jo positivity in spring and anti-SRP in autumn $[74,75]$.

An association between anti-Mi2-positive DM and surface ultraviolet radiation exposure has also been demonstrated [76]. In JDM different birth patterns have been observed for patients with and without anti-TIF1Y antibodies, suggesting perinatal or early life exposures may play a role [77].

The increased prevalence of anti-MDA5-positive DM in Eastern Asia may reflect differences in significant environmental exposures or racial genetic background. A recent study confirmed the observed increasing frequency of anti-MDA5-positive patients amongst DM patients in central Japan, and established regional differences suggesting that environmental factors may contribute [78]. Melanoma associated differentiation gene 5, the antigenic target of anti-MDA5 autoantibodies, is involved in the innate immune system and host defence against picornaviruses [79]. It may play a wider role in infection, however, and increased MDA5 mRNA expression has been found in gastric mucosal cells infected with Helicobacter pylori [80].

\section{Genetic factors}

In contrast to the multiple differences in clinical features between adult and juvenile DM, genetic evidence to date 
has been remarkably overlapping for the two groups. It is well established that the MHC, also known as the human leukocyte antigen (HLA) system, confers susceptibility to a variety of autoimmune diseases, including DM in both adults and children. Thus, in predominantly Caucasian populations the HLA 8.1 ancestral haplotype (HLAB*08/DRB1*03/DQA1*05/DQB1*02) has been linked to increased risk of many autoimmune diseases, including adult DM and JDM [44]. In similar JDM populations there is also evidence that the TNF-308A allele, a single nucleotide polymorphism, may be a risk factor for calcinosis and prolonged disease course, although this is also in strong linkage disequilibrium with the HLA 8.1 ancestral haplotype. The association between the HLA 8.1 haplotype has been shown to be stronger in certain autoantibody subgroups, namely anti-Jo1 and anti-PmScl [81]. These data show that genetic background modifies clinical presentation; results from a recently completed, genome-wide association study of adult DM and JDM may shed light on other important loci implicated in pathogenesis [33]. In JDM, familial aggregation of specific autoimmune diseases has been seen, including type 1 diabetes mellitus and systemic lupus erythematosus, suggesting shared pathogenic factors and possibly rare causal genes with large effects [82]. Given the potentially different aetiologies of malignancy-associated and non-malignancy-associated DM, it would be interesting to compare the genetic background of these two groups.

\section{Conclusion}

Whilst adult DM and JDM share the hallmark disease characteristics of classical rash and muscle weakness, the frequency of other disease features varies with age of onset. Important clinical features such as ILD and malignancy are less common in younger adults and rarely seen in children. Conversely, cutaneous features such as calcinosis are more of a disease burden in younger patients. These differences may reflect different disease triggers between children and adults, either external environmental factors or internal factors such as the development of malignancy. Clinical differences between adults and children within autoantibody subgroups are likely to reflect modification of the disease response by more rapidly growing muscle in children, and age-related differences in cellular processing and the immune response.

Our understanding of the mechanisms that underlie these differences is limited by a lack of studies directly comparing adults and children both clinically and histologically. Further work in this area may greatly increase our understanding of the disease process in DM and the modifying factors affecting the development of significant clinical complications.
This article is part of the series on Childhood rheumatic diseases, edited by Patricia Woo. Other articles in this series can be found at http://arthritis-research.com/series/childhood

\section{Abbreviations}

$\mathrm{CT}$, computed tomography; DM, dermatomyositis; HLA, human leukocyte antigen; HRCT, high-resolution computed tomography; ILD, interstitial lung disease; JDM, juvenile dermatomyositis; MHC, major histocompatibility complex; MSA, myositis-specific antibody; NSIP, non-specific intestitial pneumonia; TNF, tumour necrosis factor; UIP, usual interstitial pneumonia.

\section{Competing interests}

The authors declare that they have no competing interests.

\section{Acknowledgements}

The JDM Cohort Study has been supported by generous grants from the Cathal Hayes Research Trust, the Wellcome Trust UK (085860), Action Medical Research UK (SP4252), The Henry Smith Charity, Arthritis Research UK (14518 and 18796), Raynaud's and Scleroderma Association and the UK Myositis Support Group. The study has been adopted onto the Comprehensive Research Network through the Medicines for Children Research Network (MCRN). The Juvenile Dermatomyositis Research Group would like to thank all of the patients and their families who contributed to the Juvenile Dermatomyositis Cohort Study. We thank all local research coordinators and principal investigators who have made this research possible. The members who contributed were as follows: Dr Kate Armon, Mr Joe Ellis-Gage and Ms Holly Roper (Norfolk and Norwich University Hospitals); Dr Liza McCann, Mr lan Roberts, Dr Eileen Baildam, Ms Louise Hanna and Ms Olivia Lloyd (The Royal Liverpool Children's Hospital, Alder Hey, Liverpool); Dr Phil Riley and Ms Ann McGovern (Royal Manchester Children's Hospital, Manchester); Dr Clive Ryder and Mrs Janis Scott (Birmingham Children's Hospital, Birmingham); Dr Sue Wyatt, Mrs Gillian Jackson, Dr Tania Amin, Mark Wood and Vanessa VanRooyen (Leeds General Infirmary, Leeds); Dr Joyce Davidson, Dr Janet Gardner-Medwin, Dr Neil Martin, Ms Sue Ferguson and Ms Liz Waxman (The Royal Hospital for Sick Children, Yorkhill, Glasgow); Dr Mark Friswell, Professor Helen Foster, Mrs Alison Swift, Dr Sharmila Jandial, Ms Vicky Stevenson, Ms Debbie Wade, Dr Ethan Sen and Ms Lisa Qiao (Great North Children's Hospital, Newcastle); Dr Helen Venning, Dr Rangaraj Satyapal, Mrs Elizabeth Stretton and Ms Mary Jordan (Queens Medical Centre, Nottingham); Professor Lucy Wedderburn, Dr Clarissa Pilkington, Dr N Hasson, Mrs Sue Maillard, Ms Elizabeth Halkon, Ms Virginia Brown, Ms Audrey Juggins, Dr Sally Smith, Mrs Sian Lunt, Ms Elli Enayat, Mrs Hemlata Varsani, Miss Laura Beard and Miss Katie Arnold (Great Ormond Street Hospital, London); Dr Kevin Murray (Princess Margaret Hospital, Perth, Western Australia); Dr John loannou and Ms Linda Suffield (University College London Hospital).

\section{Author details}

'Rheumatology Department, Royal National Hospital for Rheumatic Diseases, Bath BA1 1RL, UK. 2Rheumatology Unit, UCL Institute of Child Health, 30 Guilford Street, London WC1N 1EH, UK.

\section{Published: 8 April 2013}

\section{References}

1. Bendewald MJ: Incidence of dermatomyositis and clinically amyopathic dermatomyositisa population-based study in Olmsted County, Minnesota. Arch Dermatol 2010, 146:26.

2. Symmons DP, Sills JA, Davis SM: The incidence of juvenile dermatomyositis: results from a nation-wide study. Br J Rheumatol 1995, 34:732-736.

3. Mendez EP, Lipton R, Ramsey-Goldman R, Roettcher P, Bowyer S, Dyer A, Pachman LM; NIAMS Juvenile DM Registry Physician Referral Group: US incidence of juvenile dermatomyositis, 1995-1998: Results from the National Institute of Arthritis and Musculoskeletal and Skin Diseases Registry. Arthritis Rheum 2003, 49:300-305.

4. McCann LJ, Juggins AD, Maillard SM, Wedderburn LR, Davidson JE, Murray KJ, Pilkington CA; Juvenile Dermatomyositis Research Group: The Juvenile Dermatomyositis National Registry and Repository (UK and Ireland) clinical characteristics of children recruited within the first $5 \mathrm{yr}$. Rheumatology 2006, 45:1255-1260

5. Ravelli A, Trail L, Ferrari C, Ruperto N, Pistorio A, Pilkington C, Maillard S, 
Oliveira SK, Sztajnbok F, Cuttica R, Beltramelli M, Corona F, Katsicas MM, Russo R, Ferriani V, Burgos-Vargas R, Magni-Manzoni S, Solis-Valleoj E, Bandeira M, Zulian F, Baca V, Cortis E, Falcini F, Alessio M, Alpigiani MG, Gerloni V, SaadMagalhaes C, Podda R, Silva CA, Lepore L, et al:: Long-term outcome and prognostic factors of juvenile dermatomyositis: A multinational, multicenter study of 490 patients. Arthritis Care Res 2010, 62:63-72.

6. Rider LG, Lachenbruch PA, Monroe JB, Ravelli A, Cabalar I, Feldman BM, Villalba ML, Myones BL, Pachman LM, Rennebohm RM, Reed AM, Miller FW; IMACS Group: Damage extent and predictors in adult and juvenile dermatomyositis and polymyositis as determined with the myositis damage index. Arthritis Rheum 2009, 60:3425-3435.

7. Bowyer SL, Blane CE, Sullivan DB, Cassidy JT: Childhood dermatomyositis: factors predicting functional outcome and development of dystrophic calcification. J Pediatrics 1983, 103:882-888.

8. Ramanan AV, Campbell-Webster N, Ota S, Parker S, Tran D, Tyrrell PN, Cameron B, Spiegel L, Schneider R, Laxer RM, Silverman ED, Feldman BM: The effectiveness of treating juvenile dermatomyositis with methotrexate and aggressively tapered corticosteroids. Arthritis Rheum 2005, 52:3570-3578.

9. Fisler RE, Liang MG, Fuhlbrigge RC, Yalcindag A, Sundel RP: Aggressive management of juvenile dermatomyositis results in improved outcome and decreased incidence of calcinosis. J Am Acad Dermatol 2002, 47:505-511.

10. Pachman LM, Hayford JR, Chung A, Daugherty CA, Pallansch MA, Fink CW, Gewanter HL, Jerath R, Lang BA, Sinacore J, Szer IS, Dyer AR, Hochberg MC Juvenile dermatomyositis at diagnosis: clinical characteristics of 79 children. J Rheum 1998, 25:1198-1204.

11. Gerami P, Walling HW, Lewis J, Doughty L, Sontheimer RD: A systematic review of juvenile-onset clinically amyopathic dermatomyositis. Br J Dermatol 2007, 157:637-644.

12. McCann LJ, Li CKC, Varsani H, Wedderburn LR, Pilkington CA: Failure to over express MHC-CLASS-1 on muscle biopsy in a case of amyopathic juvenile dermatomyositis. Clin Exp Rheumatol 2007, 25:96-98.

13. Callen JPJ: Relation between dermatomyositis and polymyositis and cancer. Lancet 2001, 357:85-86

14. Buchbinder R, Hill CL: Malignancy in patients with inflammatory myopathy. Curr Rheumatol Rep 2002, 4:415-426.

15. Hill CL, Zhang Y, Sigurgeirsson B, Pukkala E, Mellemkjaer L, Airio A, Evans SR, Felson DT: Frequency of specific cancer types in dermatomyositis and polymyositis: a population-based study. Lancet 2001, 357:96-100.

16. Buchbinder R, Forbes A, Hall S, Dennett X, Giles G: Incidence of malignant disease in biopsy-proven inflammatory myopathy. A population-based cohort study. Ann Intern Med 2001, 134:1087-1095.

17. Morris P, Dare J: Juvenile dermatomyositis as a paraneoplastic phenomenon: an update. J Pediatr Hematol Oncol 2010, 32:189-191.

18. Marie I, Hatron PY, Hachulla E, Wallaert B, Michon-Pasturel U, Devulder B: Pulmonary involvement in polymyositis and in dermatomyositis. I Rheum 1998, 25:1336-1343.

19. Kang EH, Lee EB, Shin KC, Im CH, Chung DH, Han SK, Song YW: Interstitial lung disease in patients with polymyositis, dermatomyositis and amyopathic dermatomyositis. Rheumatology 2005, 44:1282-1286.

20. Fathi $M$, Lundberg IE: Interstitial lung disease in polymyositis and dermatomyositis. Curr Opin Rheum 2005, 17:701-706.

21. Marie I, Hachulla E, Chérin P, Dominique S, Hatron PY, Hellot MF, Devulder B, Herson S, Levesque $\mathrm{H}$, Courtois $\mathrm{H}$ : Interstitial lung disease in polymyositis and dermatomyositis. Arthritis Rheum 2002, 47:614-622.

22. Cottin V, Thivolet-Béjui F, Reynaud-Gaubert M, Cadranel J, Delaval P, Ternamian PJ, Cordier JF; Groupe d'Etudes et de Recherche sur les Maladies "Orphelines" Pulmonaires: Interstitial lung disease in amyopathic dermatomyositis, dermatomyositis and polymyositis. Eur Respir J 2003, 22:245-250.

23. Sato S, Kuwana M: Clinically amyopathic dermatomyositis. Curr Opin Rheum 2010, 22:639-643

24. Gutsche M, Rosen GD, Swigris JJ: Connective tissue disease-associated interstitial lung disease: a review. Curr Respir Care Rep 2012, 1:224-232.

25. Richards TJ, Eggebeen A, Gibson K, Yousem S, Fuhrman C, Gochuico BR, Fertig $\mathrm{N}$, Oddis CV, Kaminski N, Rosas IO, Ascherman DP: Characterization and peripheral blood biomarker assessment of anti-Jo-1 antibody-positive interstitial lung disease. Arthritis Rheum 2009, 60:2183-2192.

26. Kalluri M, Sahn SA, Oddis CV, Gharib SL, Christopher-Stine L, Danoff SK, Casciola-Rosen L, Hong G, Dellaripa PF, Highland KB: Clinical profile of antiPL-12 autoantibody: cohort study and review of the literature. Chest 2009,
135:1550-1556.

27. Robinson $A B$, Reed $A M$ : Clinical features, pathogenesis and treatment of juvenile and adult dermatomyositis. Nat Rev Rheumatol 2011, 7:664-675.

28. Trapani S, Camiciottoli G, Vierucci A, Pistolesi M, Falcini F: Pulmonary involvement in juvenile dermatomyositis: a two-year longitudinal study. Rheumatology 2001, 40:216-220

29. Kobayashi I, Yamada M, Takahashi Y, Kawamura N, Okano M, Sakiyama Y, Kobayashi $\mathrm{K}$ : Interstitial lung disease associated with juvenile dermatomyositis: clinical features and efficacy of cyclosporin A. Rheumatology 2003, 42:371-374.

30. Sanner H, Aalokken TM, Gran JT, Sjaastad I, Johansen B, Flato B: Pulmonary outcome in juvenile dermatomyositis: a case-control study. Ann Rheum Dis 2010, 70:86-91.

31. Huber AM, Feldman BM: Medium and long term functional outcomes in a mulitcenter cohort of children with juvenile dermatomyositis. Arthritis Rheum 2000, 43:541-549.

32. Feldman $B M$, Rider $L G$, Reed $A M$, Pachman $L M$ : Juvenile dermatomyositis and other idiopathic inflammatory myopathies of childhood. Lancet 2008 371:2201-2212.

33. Pachman LM, Liotta-Davis MR, Hong DK, Kinsella TR, Mendez EP, Kinder JM, Chen EH: TNF alpha-308A allele in juvenile dermatomyositis: association with increased production of tumor necrosis factor alpha, disease duration, and pathologic calcifications. Arthritis Rheum 2000, 43:2368-2377.

34. Balin SJ, Wetter DA, Andersen LK, Davis MDP: Calcinosis cutis occurring in association with autoimmune connective tissue disease: the Mayo Clinic Experience with 78 patients, 1996-2009. Arch Dermatol 2012, 148:455-462.

35. Lowry CA, Pilkington CA: Juvenile dermatomyositis: extramuscular manifestations and their management. Curr Opin Rheum 2009, 21:575-580.

36. Martin N, Krol P, Smith S, Beard L, Pilkington CA, Davidson J, Wedderburn LR; Juvenile Dermatomyositis Research Group (JDRG): A comparison of children with onset of juvenile dermatomyositis symptoms before or after their fifth birthday in the UK and Ireland JDM Cohort study. Arthritis Care Res 2012, 64:1665-1672.

37. Li CK, Knopp P, Moncrieffe H, Singh B, Shah S, Nagaraju K, Varsani H, Gao B, Wedderburn LR: Overexpression of MHC class I heavy chain protein in young skeletal muscle leads to severe myositis: implications for juvenile myositis. Am J Pathol 2009, 175:1030-1040.

38. Gibson MC, Schultz E: Age-related differences in absolute numbers of skeletal muscle satellite cells. Muscle Nerve 1983, 6:574-580.

39. Gunawardena H, Betteridge ZE, McHugh NJ: Myositis-specific autoantibodies: their clinical and pathogenic significance in disease expression. Rheumatology 2009, 48:607-612.

40. Hoshino K, Muro Y, Sugiura K, Tomita Y, Nakashima R, Mimori T: Anti-MDA5 and anti-TIF1- antibodies have clinical significance for patients with dermatomyositis. Rheumatology 2010, 49:1726-1733.

41. Matsushita T, Hasegawa M, Fujimoto M, Hamaguchi Y, Komura K, Hirano T, Horikawa M, Kondo M, Orito H, Kaji K, Saito Y, Matsushita Y, Kawara S, Yasui M, Seishima M, Ozaki S, Kuwana M, Ogawa F, Sato S, Takehara K: Clinical evaluation of anti-aminoacyl tRNA synthetase antibodies in Japanese patients with dermatomyositis. J Rheum 2007, 34:1012-1018.

42. Hervier B, Wallaert B, Hachulla E, Adoue D, Lauque D, Audrain M, Camara B, Fournie B, Couret B, Hatron PY, Dubucquoi S, Hamidou M: Clinical manifestations of anti-synthetase syndrome positive for anti-alanyl-tRNA synthetase (anti-PL12) antibodies: a retrospective study of 17 cases. Rheumatology 2010, 49:972-976

43. Rider LG, Miller FW, Targoff IN, Sherry DD, Samayoa E, Lindahl M, Wener MH, Pachman LM, Plotz PH: A broadened spectrum of juvenile myositis. Myositis-specific autoantibodies in children. Arthritis Rheum 1994, 37:1534-1538.

44. Wedderburn LR, McHugh NJ, Chinoy H, Cooper RG, Salway F, Ollier WE, McCann LJ, Varsani H, Dunphy J, North J, Davidson JE; Juvenile Dermatomyositis Research Group (JDRG): HLA class II haplotype and autoantibody associations in children with juvenile dermatomyositis and juvenile dermatomyositis scleroderma overlap. Rheumatology 2007, 46:1786-1791

45. Targoff IN, Reichlin M: The association between Mi-2 antibodies and dermatomyositis. Arthritis Rheum 1985, 28:796-803.

46. Feldman BM, Reichlin M, Laxer RM, Targoff IN, Stein LD, Silverman ED: Clinical significance of specific autoantibodies in juvenile dermatomyositis. J Rheum 1996, 23:1794-1797.

47. Fujimoto M, Hamaguchi Y, Kaji K, Matsushita T, Ichimura Y, Kodera M, Ishiguro 
N, Ueda-Hayakawa I, Asano Y, Ogawa F, Fujikawa K, Miyagi T, Mabuchi E, Hirose K, Akimoto N, Hatta N, Tsutsui K, Higashi A, Igarashi A, Seishima M, Hasegawa M, Takehara K: Myositis-specific anti-155/140 autoantibodies target transcription intermediary factor 1 family proteins. Arthritis Rheum 2012, 64:513-522

48. Targoff IN, Mamyrova G, Trieu EP, Perurena O, Koneru B, O'Hanlon TP, Miller FW, Rider LG; Childhood Myositis Heterogeneity Study Group; International Myositis Collaborative Study Group: A novel autoantibody to a $155-\mathrm{kd}$ protein is associated with dermatomyositis. Arthritis Rheum 2006 54:3682-3689

49. Kaji K, Fujimoto M, Hasegawa M, Kondo M, Saito Y, Komura K, Matsushita T, Orito H, Hamaguchi Y, Yanaba K, Itoh M, Asano Y, Seishima M, Ogawa F, Sato S, Takehara K: Identification of a novel autoantibody reactive with 155 and $140 \mathrm{kDa}$ nuclear proteins in patients with dermatomyositis: an association with malignancy. Rheumatology 2007, 46:25-28.

50. Gunawardena H, Wedderburn LR, North J, Betteridge Z, Dunphy J, Chinoy H Davidson JE, Cooper RG, McHugh NJ; Juvenile Dermatomyositis Research Group UK: Clinical associations of autoantibodies to a p155/140 kDa doublet protein in juvenile dermatomyositis. Rheumatology 2008, 47:324-328.

51. Bingham A, Mamyrova G, Rother Kl, Oral E, Cochran E, Premkumar A, Kleiner D, James-Newton L, Targoff IN, Pandey JP, Carrick DM, Sebring N, O'Hanlon TP, Ruiz-Hidalgo M, Turner M, Gordon LB, Laborda J, Bauer SR, Blackshear PJ, Imundo L, Miller FW, Rider LG; Childhood Myositis Heterogeneity Study Group: Predictors of acquired lipodystrophy in juvenile-onset dermatomyositis and a gradient of severity. Medicine 2008, 87:70-86.

52. Espada G, Maldonado Cocco J, Fertig N, Oddis CV: Clinical and serologic characterization of an Argentine pediatric myositis cohort: identification of a novel autoantibody (anti-MJ) to a 142-kDa protein. J Rheum 2009, 36:2547-2551

53. Gunawardena $H$, Wedderburn $L R$, Chinoy $H$, Betteridge ZE, North J, Ollier WE, Cooper RG, Oddis CV, Ramanan AV, Davidson JE, McHugh NJ; Juvenile Dermatomyositis Research Group, UK and Ireland: Autoantibodies to a 140-kd protein in juvenile dermatomyositis are associated with calcinosis. Arthritis Rheum 2009, 60:1807-1814.

54. Ichimura Y, Matsushita T, Hamaguchi Y, Kaji K, Hasegawa M, Tanino Y, Inokoshi Y, Kawai K, Kanekura T, Habuchi M, Igarashi A, Sogame R, Hashimoto T, Koga T, Nishino A, Ishiguro N, Sugimoto N, Aoki R, Ando N, Abe T, Kanda T, Kuwana M, Takehara K, Fujimoto M: Anti-NXP2 autoantibodies in adult patients with idiopathic inflammatory myopathies: possible association with malignancy. Ann Rheum Dis 2012, 71:710-713.

55. Ceribelli A, Fredi M, Taraborelli M, Cavazzana I, Franceschini F, Quinzanini M, Tincani A, Ross SJ, Chan JY, Pauley BA, Chan EK, Satoh M: Anti-MJ/NXP-2 autoantibody specificity in a cohort of adult Italian patients with polymyositis/dermatomyositis. Arthritis Res Ther 2012, 14:R97.

56. Sato S, Hoshino K, Satoh T, Fujita T, Kawakami Y, Fujita T, Kuwana M: RNA helicase encoded by melanoma differentiation-associated gene 5 is a major autoantigen in patients with clinically amyopathic dermatomyositis: Association with rapidly progressive interstitial lung disease. Arthritis Rheum 2009, 60:2193-2200.

57. Nakashima R, Imura Y, Kobayashi S, Yukawa N, Yoshifuji H, Nojima T, Kawabata D, Ohmura K, Usui T, Fujii T, Okawa K, Mimori T: The RIG-I-like receptor IFIH1/ MDA5 is a dermatomyositis-specific autoantigen identified by the antiCADM-140 antibody. Rheumatology 2010, 49:433-440.

58. Fiorentino D, Chung L, Zwerner J, Rosen A, Casciola-Rosen L: The mucocutaneous and systemic phenotype of dermatomyositis patients with antibodies to MDA5 (CADM-140): A retrospective study. J Am Acad Dermatol 2011, 65:25-34

59. Gono T, Sato S, Kawaguchi Y, Kuwana M, Hanaoka M, Katsumata Y, Takagi K, Baba S, Okamoto Y, Ota Y, Yamanaka H: Anti-MDA5 antibody, ferritin and IL-18 are useful for the evaluation of response to treatment in interstitial lung disease with anti-MDA5 antibody-positive dermatomyositis. Rheumatology 2012, 51:1563-1570.

60. Koga T, Fujikawa K, Horai Y, Okada A, Kawashiri SY, Iwamoto N, Suzuki T, Nakashima Y, Tamai M, Arima K, Yamasaki S, Nakamura H, Origuchi T, Hamaguchi Y, Fujimoto M, Ishimatsu Y, Mukae H, Kuwana M, Kohno S, Eguchi K, Aoyagi K, Kawakami A: The diagnostic utility of anti-melanoma differentiation-associated gene 5 antibody testing for predicting the prognosis of Japanese patients with DM. Rheumatology 2012, 51:1278-1284

61. Tanizawa K, Handa T, Nakashima R, Kubo T, Hosono Y, Watanabe K, Aihara K,
Oga T, Chin K, Nagai S, Mimori T, Mishima M: HRCT features of interstitial lung disease in dermatomyositis with anti-CADM-140 antibody. Respir Med 2011, 105:1380-1387.

62. Kobayashi I, Okura Y, Yamada M, Kawamura N, Kuwana M, Ariga T: Antimelanoma differentiation-associated gene 5 antibody is a diagnostic and predictive marker for interstitial lung diseases associated with juvenile dermatomyositis. J Pediatrics 2011, 158:675-677.

63. Betteridge ZE, Gunawardena H, Chinoy H, North J, Ollier WE, Cooper RG, McHugh NJ; UK Adult Onset Myositis Immunogenetic Collaboration: Clinical and human leucocyte antigen class II haplotype associations of autoantibodies to small ubiquitin-like modifier enzyme, a dermatomyositis-specific autoantigen target, in UK Caucasian adult-onset myositis. Ann Rheum Dis 2009, 68:1621-1625.

64. Targoff IN, Johnson AE, Miller FW: Antibody to signal recognition particle in polymyositis. Arthritis Rheum 1990, 33:1361-1370.

65. Hengstman GJ, ter Laak HJ, Vree Egberts WT, Lundberg IE, Moutsopoulos HM Vencovsky J, Doria A, Mosca M, van Venrooij WJ, van Engelen BG: Anti-signal recognition particle autoantibodies: marker of a necrotising myopathy. Ann Rheum Dis 2006, 65:1635-1638.

66. Rouster-Stevens KA, Pachman LM: Autoantibody to signal recognition particle in African American girls with juvenile polymyositis. J Rheum 2008 35:927-929.

67. Casciola-Rosen L: Enhanced autoantigen expression in regenerating muscle cells in idiopathic inflammatory myopathy. J Exp Med 2005, 201:591-601.

68. Dupont S, Mamidi A, Cordenonsi M, Montagner M, Zacchigna L, Adorno M, Martello G, Stinchfield MJ, Soligo S, Morsut L, Inui M, Moro S, Modena N, Argenton F, Newfeld SJ, Piccolo S: FAM/USP9x, a deubiquitinating enzyme essential for TGFbeta signaling, controls Smad4 monoubiquitination. Cell 2009, 136:123-135

69. Takahashi K, Yoshida N, Murakami N, Kawata K, Ishizaki H, Tanaka-Okamoto M, Miyoshi J, Zinn AR, Shime H, Inoue N: Dynamic regulation of p53 subnuclear localization and senescence by MORC3. Mol Biol Cell 2007, 18:1701-1709

70. Bowles NE, Dubowitz V, Sewry CA, Archard LC: Dermatomyositis, polymyositis, and Coxsackie-B-virus infection. Lancet 1987, 1:1004-1007.

71. Topi GC, D'Alessandro L, Catricala C, Zardi O: Dermatomyositis-like syndrome due to toxoplasma. Br J Dermatol 1979, 101:589-591.

72. Mamyrova G, Rider LG, Haagenson L, Wong S, Brown KE: Parvovirus B19 and onset of juvenile dermatomyositis. JAMA 2005, 294:2170-2171.

73. Reed AM, Ytterberg SR: Genetic and environmental risk factors for idiopathic inflammatory myopathies. Rheum Dis Clin North Am 2002, 28:891-916.

74. Leff RL, Burgess SH, Miller FW, Love LA, Targoff IN, Dalakas MC, Joffe MM, Plotz $\mathrm{PH}$ : Distinct seasonal patterns in the onset of adult idiopathic inflammatory myopathy in patients with anti-Jo- 1 and anti-signal recognition particle autoantibodies. Arthritis Rheum 1991, 34:1391-1396.

75. Sarkar K, Weinberg CR, Oddis CV, Medsger TA Jr, Plotz PH, Reveille JD, Arnett FC, Targoff IN, Genth E, Love LA, Miller FW: Seasonal influence on the onset of idiopathic inflammatory myopathies in serologically defined groups. Arthritis Rheum 2005, 52:2433-2438.

76. Okada S, Weatherhead E, Targoff IN, Wesley R, Miller FW, for the International Myositis Collaborative Study Group: Global surface ultraviolet radiation intensity may modulate the clinical and immunologic expression of autoimmune muscle disease. Arthritis Rheum 2003, 48:2285-2293.

77. Vegosen $L$, Weinberg CR, O'Hanlon TP, Targoff IN, Miller FW, Rider LG: Seasonal birth patterns in myositis subgroups suggest an etiologic role of early environmental exposures. Arthritis Rheum 2007, 56:2719-2728.

78. Muro Y, Sugiura K, Hoshino K, Akiyama M, Tamakoshi K: Epidemiologic study of clinically amyopathic dermatomyositis and anti-melanoma differentiation-associated gene 5 antibodies in central Japan. Arthritis Res Ther 2011, 13:R214.

79. Kato H, Takeuchi O, Sato S, Yoneyama M, Yamamoto M, Matsui K, Uematsu S, Jung A, Kawai T, Ishii KJ, Yamaguchi O, Otsu K, Tsujimura T, Koh CS, Reis e Sousa C, Matsuura Y, Fujita T, Akira S: Differential roles of MDA5 and RIG-I helicases in the recognition of RNA viruses. Nature 2006, 441:101-105.

80. Tatsuta T, Imaizumi T, Shimoyama T, Sawaya M, Kunikazu T, Matsumiya T, Yoshida H, Satoh K, Fukuda S: Expression of melanoma differentiation associated gene 5 is increased in human gastric mucosa infected with Helicobacter pylori. J Clin Pathol 2012, 65:839-843.

81. Chinoy H, Li CK, Platt H, Fertig N, Varsani H, Gunawardena H, Betteridge Z, 
Oddis CV, McHugh NJ, Wedderburn LR, Ollier WE, Cooper RG; UK Adult Onset Myositis Immunogenetic Consortium and UK Juvenile Dermatomyositis

Research Group: Genetic association study of NF- B genes in UK Caucasian adult and juvenile onset idiopathic inflammatory myopathy. Rheumatology 2012, 51:794-799.

82. Niewold TB, Wu SC, Smith M, Morgan GA, Pachman LM: Familial aggregation of autoimmune disease in juvenile dermatomyositis. Pediatrics 2011,

127:e1239-1246. doi:10.1186/ar4198

Cite this article as: Tansley SL, et al:: Adult and juvenile dermatomyositis: are the distinct clinical features explained by our current understanding

of serological subgroups and pathogenic mechanisms?. Arthritis Research \& Therapy 2013, 15:211. 